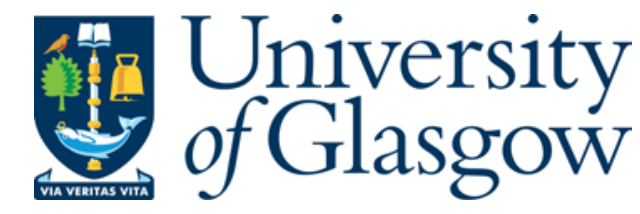

Foster, S. (2010) The curatorial consequences of being moved, moveable or portable: the case of carved stones. Scottish Archaeological Journal, 32 . pp. 15-28. ISSN 1471-5767

http://eprints.gla.ac.uk/43985/

Deposited on: 18 July 2012

Enlighten - Research publications by members of the University of Glasgow http://eprints.gla.ac.uk 


\title{
The curatorial consequences of being moved, moveable or portable: the case of carved stones
}

\author{
SALLY M. FOSTER ${ }^{1}$
}

\begin{abstract}
SUMMARY
It matters whether a carved stone is moved, moveable or portable because this influences perceptions of significance and of form and nature. Is it a monument or an artefact? This duality may in turn affect understanding and appreciation of the resource. It has implications for how and if carved stones can be legally protected, who owns them, where and how they are administered, and by whom. The complexities of the legislation mean that all too often this is also a grey area. This paper explores these curatorial issues and their impact.
\end{abstract}

KEYWORDS: sculpture, artefacts, monuments, meaning, dual identity

Scottish carved stones offer a great arena for exploring the relationship between artefacts and archaeological sites or monuments. 'Carved stones' is an umbrella term for the extraordinary variety of such stones that have been produced over 5,000 years or more, and from which we can learn much about the lives of the people who lived here over that period - from prehistoric rock art to architectural sculpture to gravestones. Such a rich and varied resource is a particularly important cultural asset for Scotland. From the point of view of techniques of conservation, many of us find a value in this umbrella term because carved stones of all types are vulnerable to the same range of threats. But it is also useful because of common issues that can arise in the protection, conservation, management and interpretation of this aspect of the historic environment.

In Scotland, we have pioneered many of the philosophical and technical approaches to dealing with carved stones. We have therefore encountered and exposed the multiple and fragmented identities that attach to carved stones in contemporary society and the issues that arise from this. We also know that archaeological sites and monuments are part of our national and local identity. They contribute to our history and education, tourism, sustainability,

${ }^{1}$ Department of Archaeology, University of Aberdeen, St Mary's Building, Elphinstone Road, Aberdeen AB24 3UF, email: ableminds@btinternet.com

Scottish Archaeological Journal 32.1 (2010): 15-28 Edinburgh University Press DOI: 10.3366/saj.2011.0005 (C) Glasgow Archaeological Society www.eupjournals.com/saj 
local distinctiveness, placemaking and quality of life. Everyone's interest in the past is therefore unavoidably political. Over the last 120 years we can chart occasional contested and, on rare occasions, very high profile cases where the key issue - superficially at least - has been where carved stones are best preserved (Foster 2001; 2005; Jones 2004; 2005a; 2005b; 2006). In this, the key players were and continue to be landowners, local communities, local and national antiquarian societies, local and national museums and other state bodies. On more than one occasion, the solution has involved Secretaries of State (Dupplin, Perthshire and Kinross: Foster 2001, 18; Hilton of Cadboll, Highland: James et al 2008).

My thesis is that the root of this very modern situation is whether we perceive and treat carved stones as artefacts or monuments, and the extent to which this then drives our curatorial approach to their future. Present regulatory and operational circumstances mean that it matters whether a carved stone is moved, moveable or portable. This automatically influences perceptions of significance and of form and nature-is it a monument or an artefact? This duality may in turn affect understanding and appreciation of the resource. It has implications for how and if carved stones can be legally protected, who owns them, where and how they are administered, and by whom.

\section{CASE Histories}

A rapid overview of two case histories will serve to illustrate some of the points that will follow. These are extreme cases - each with unique circumstances - but they raise interesting points that do have a wider resonance.

\section{The impact of the first ancient monuments legislation in 1882}

In 1882, moveable carved stones, such as had previously been presented to or acquired by the National Museum of Antiquities, came within the scope of the first ancient monuments legislation, the Ancient Monuments Protection Act. This led to a public debate about where sculpture is best looked after, a dialogue that is documented in the writings of Joseph Anderson, the museum curator, and General Pitt Rivers, the first Inspector of Ancient Monuments for Great Britain (Foster 2001, 3-14). The subject matter was what we now know as early-medieval carved stones. Their polar views stem from radically different philosophies about how the public best appreciate the value of this material, although both had the common aim of raising public awareness and support for the sculpture. This debate has to be set against a wider political context that included some Scottish hostility to an Inspector with new powers, working from an Office of Works that was clearly part of the British state and based south of the border. But, the crux of the matter was whether the prime value of [early-medieval] sculpture lay in its recognition as a highly artistic artefact collected, celebrated and accessible in a single (national) museum or as a collection of preserved monuments still associated with their place of creation, use or discovery.

Pitt Rivers' reasoning for keeping carved stones locally can be summarised as follows: 
- A reluctance to deprive country places of their old associations and of things that draw people to visit them. This was also expressed in terms of robbing or sacrificing country places in the interests of towns and foreigners

- Minor monuments could be overlooked if collected together with others in an over-crowded museum

- The patterns of local diversity would be less obvious

- Moving to a museum results in 'dissociation with the region to which they belong'

- If public interest was not generated in such monuments then there would be no pressure on government to fund necessary works to protect them (ibid, 8-9).

For those of us involved in, or familiar with, recent carved stones casework, there is a familiar ring to some of this 1890s rhetoric: compare for example late 19thcentury Dyce, in Aberdeenshire, which was the case which led Pitt Rivers to crystallise his ideas (ibid, 8-14 and Appendix) with the early $21^{\text {st }}$-century events at Hilton of Cadboll (see below).

Anderson saw the main value of the early-medieval carved stones as 'ancient art' best displayed to generate greater public interest in a gallery where representative examples can be compared alongside each other and related art forms, as well as protected from the weather:

These wasted, mutilated, maltreated remnants of a school of art which flourished in Scotland in the dawning-time of her national history, if now rescued from the destruction which is gradually and inevitably overtaking them, would still form a magnificent gallery of the materials of that native art... It would be difficult to estimate the influence which the formation of such a representative collection in the National Museum might exercise both on the study of archaeology and on the decorative art of the country ... formation of such a gallery of art materials ... would also be an epoch in the history of art itself (Anderson 1881, 134-5).

\section{The discovery, recovery and display of the Hilton of Cadboll cross-slab}

My second example takes us up to the twenty-first century, but the story starts in the 1780s when antiquaries recognised that a large recumbent slab lying by the medieval chapel of Hilton of Cadboll was an important, ornately carved stone. In the late 1860s, the owner of the land moved the massive Pictish slab to become a feature in the gardens of his home at Invergordon Castle. This appears to have caused some upset to the local community, but the antiquarian community throughout Scotland was outraged when the owner of Invergordon Castle gave the slab to the British Museum in 1921. The outcry (an "acrimonious "repatriation" debate': Jones 2006, 107), charted in the contemporary newspapers, reached the highest levels of Scottish government and ultimately led to a change of plan, with the donation of the slab to the National Museum of Antiquities in Edinburgh. It now stands sentinel at the entrance to the Early Peoples Gallery of the Museum of Scotland.

This internationally significant slab is incomplete. The discovery in 1998 and 2001 of its missing lower portion and thousands of fragments from its 


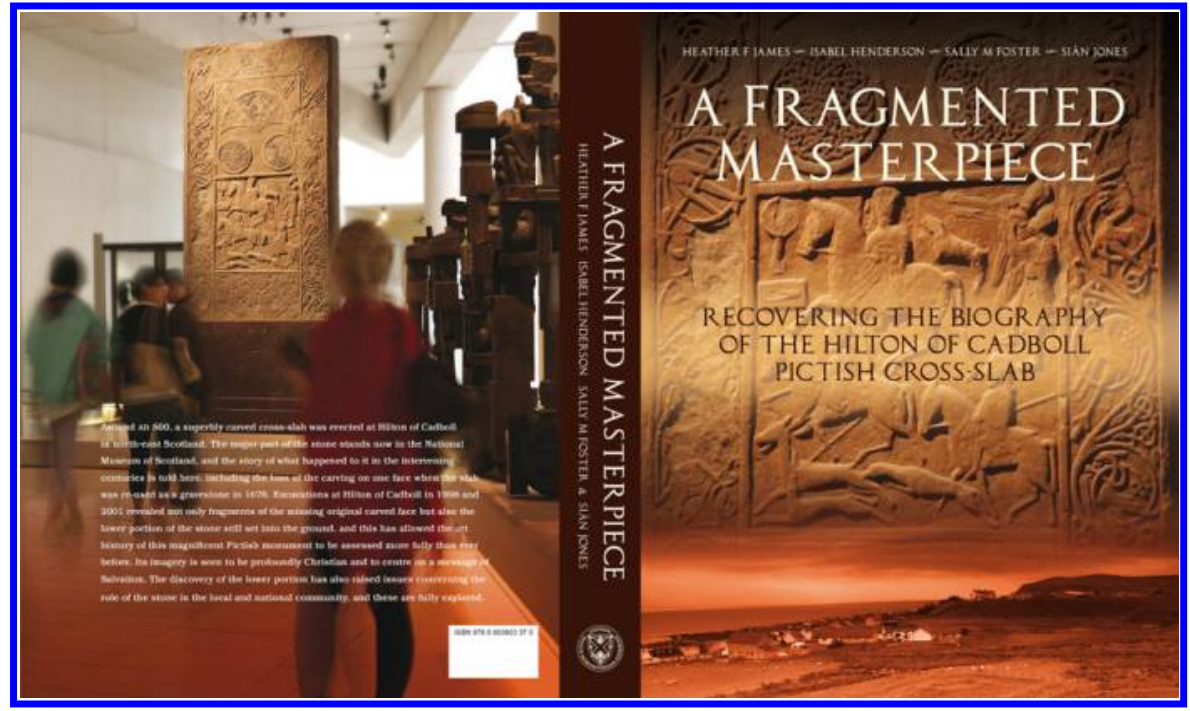

Fig 1 Carved stones can have long and complex biographies, as the Hilton of Cadboll cross-slab tells us (James et al 2008). By kind permission of the Society of Antiquaries of Scotland

defaced cross-face therefore generated enormous interest. It also re-ignited local sensitivities about where the main slab and should be preserved and displayed, introducing the newly discovered lower portion into this equation, with the local community contesting ownership and wanting the main portion returned to Hilton.

Professor Siân Jones and I explored the highly complex, 1200-year-old biography of this fragmented masterpiece of Pictish sculpture in the excavation report (James et al 2008, 205-412) (Fig 1). Jones' main focus was on the sixteenthcentury and later history of the slab through to modern perceptions of it in the Museum of Scotland, and includes the outcomes of a community study that she undertook in parallel with the archaeological fieldwork. One result of Jones' detailed study and highly nuanced analysis is that she identifies four key themes that can characterise our understanding and appreciation of the slab's history and which have resonance well beyond this particular carved stone (ibid, 265-9):

- meaning-multiple, ambiguous, contested

- identity and place-agency of specific carved stones in creating and maintaining individual, community and national perceptions of sense of place

- centre-periphery relationships-regulation versus non-regulation, evolving attitudes to nationalism, etc

- fragmentation and displacement-complex biographies of individual carved stones/assemblages; carved stone as metaphor for displacement and fragmentation of local communities.

Where and if any conflicts exist in today's carved stone management, it is likely that at least one of the above will be a factor. Hilton of Cadboll is proof that carved stones matter-people have and continue to care deeply about them, in their own 
right and for what they symbolise. Our biography does not suggest which narratives are correct or which values society should privilege, but we can demonstrate how rich meanings and values change through time, and what their implications are today.

In other publications (see bibliography), Jones further explores the themes identified above, intelligently and sensitively analysing what the Hilton of Cadboll story can tell us about wider cultural heritage practice, building on studies elsewhere in Europe, north America, Africa and Australia. In one (2005b), she picks up the threads of my first case study. Here she contrasts the tendency to celebrate national histories (whether through the creation of an 'abstract national space' - a national museum-in which there is an emphasis on a 'complete' representation of a particular type of national heritage, or the strategy of preserving representative types of monuments throughout the national landscape) with what happens on the ground, when 'official representations of national heritage are frequently recast, reformulated and contested in the production of other kinds of meaning and identity' (ibid, 96). Perhaps ironically, in the case of Hilton of Cadboll, she recognises how while contesting and recasting official national discourses, the local residents at Hilton of Cadboll have contributed to the reproduction (and indeed recasting) of the monument's national significance (ibid, 109).

\section{THE Issues}

Armed with these examples, we can now turn to the issues. My analysis suggests that there are four interlinked key areas:

- Dual identity - What is it - an artefact or a monument?

- Ownership - Whose is it?

- Stewardship - Who is responsible for looking after it?

- Philosophy-How and where should it be looked after, and why?

After briefly rehearsing each of these, I will then review how the character of modern heritage management creates and reinforces these differences.

\section{Dual identity - what is it?}

The first problem is that curators may have a different approach to when to interpret a carved stone as being an artefact or monument (Fig 2). An artefact is definable as something that humans have modified and can be of any size, type or material. The critical thing is that such features are no longer an integral [physical] part of a site or monument - they are technically portable. Any non-earthfast or non-wallfast carved stone, whatever its size, therefore can fit this bill even it is only moveable with the use of heavy machinery (also see Jones and Ralston, this volume). Yet such carved stones have very monumental qualities and are significant features in the historic landscape.

Today's interpretation of a carved stone as an artefact may of course have no relationship to the carved stone's original form and function, or its subsequent biography. A carved stone that was originally monumental in its own right-such 


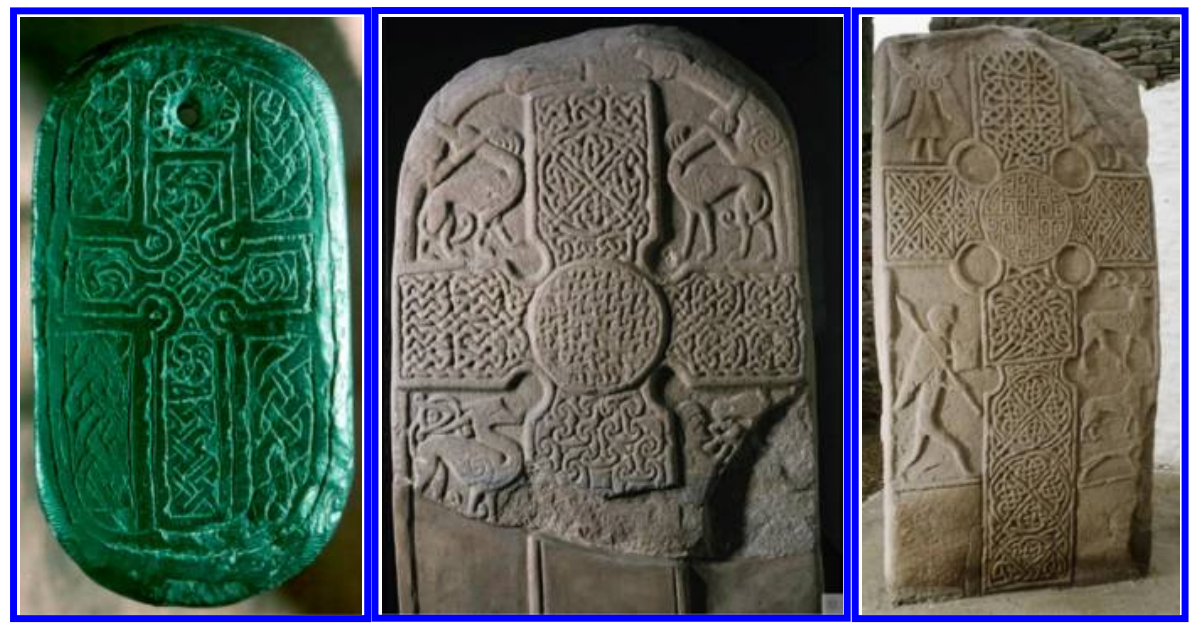

Fig 2 (a) Stone pendant from Inverness, Highland (69 mm high). (b) Pictish carved stone in Meigle Museum, Perthshire and Kinross ( $0.41 \mathrm{~m}$ high). (c) Pictish cross-slab from Eassie, Perthshire and Kinross (about 2m high). Crown copyright Historic Scotland

as a prayer cross - or formed part of a monumental structure - such as a stone altar or chancel within a church-can become portable. A range of scenarios exists for this:

- The monument became portable at some time in its immediate, recent or distant past.

- The monument was rebuilt or later incorporated into something above- or below-ground from which it is has now been physically removed.

\section{Ownership-whose is it?}

Legal ownership is an inevitable and unavoidable formality that designates who has responsibility and control for the assets in question (Jones 2004, 49). The question of who owns a carved stone depends on whether the people who implement the legislation interpret it as a 'monument' or a 'portable antiquity'. Generally, stones forming part of or permanently attached to buildings, or securely attached to ground, will be heritable and belong to the owner of the building or ground at any time. But the Crown has recently claimed some wallfast new discoveries under Treasure Trove (Curtis 2007, 343).

There is no question about new discoveries of unambiguously portable objects - it is an offence under the common law of Scotland and under the Civic Government (Scotland) Act 1982 not to report a find. It is then up to the Crown, through the Queen's and Lord Treasurer's Remembrancer (Q\&LTR) and agency of the Treasure Trove Unit and Scottish Archaeological Finds Advisory Panel, to assign ownership of new discoveries. Registered museums can bid for new finds. The outcome is that new finds may return to the finder, or go to a local or a national museum. A misconception exists that the Q\&LTR allocates most finds 'to Edinburgh'. While this is not the case, the principle of 'not splitting assemblages' 
does mean that the National Museums of Scotland (NMS) is allocated material from many sites for which it has major collections, not least for material that may have been donated to it and its originating body since 1780 (ibid, 354). There are some other complications with ownership of carved stones, particularly those on church and burial sites. Historic Scotland 2005, Appendix A attempts to summarise the ownership situation, but note some more recent changes to Treasure Trove administrative arrangements the Scottish Government Treasure Trove in Scotland: a code of practice, published in December 2008.

While most carved stones casework may be straightforward, the legal ownership question can occasionally create confusions or tensions. This happened at Hilton of Cadboll when the Q\&LTR deemed that the newly discovered parts of the cross-slab were not ownerless - and therefore outside his remit-because they belonged to the NMS who had owned the rest of the cross-slab since its donation in 1921. This is the legal concept of 'accession', in which an accessory item belongs to the owner of the principal item. Jones' work highlighted the very different perception that the local community had of this material-theirs was a social relationship rather than a legal title, expressed by a sense of belonging. She also concluded that while the conflict focused on procedural and legal frameworks relating to Treasure Trove and to aspects of conservation practice, this was only the surface manifestation of more fundamental conflicts of meaning and value: between different discourses of meaning and value surrounding a monument in its local context and the spheres of heritage management and national patrimony (Jones 2004, 13-16; 49-54; 2006).

\section{Stewardship - who is responsible for looking after it?}

When there are different understandings of 'ownership' then there is the risk of competition for responsibility for stewardship or caring for a carved stone. A monument is legally the responsibility of the individual or body that owns the land or has legal responsibility for its management (such as at a monument in state guardianship). A museum acquires legal title to an artefact. These owners have long-term curatorial responsibility for the asset in question, but we can see how bodies such as the NMS very successfully make their collections available for local display (e.g. at the Tarbat Discovery Centre, Highland), where their title to the material is not an issue. Such a pragmatic solution may be difficult if, as at Hilton of Cadboll, the ownership issue has manifested itself as the key issue when a raft of far more complex social and economic issues is the wider reality.

\section{Philosophy-how and where should it be looked after, and why?}

Others may want the ownership or stewardship function because of their convictions about where such carved stones best belong and where the best place is therefore to display them. Such beliefs stem from different emphases on what is culturally significant about particular carved stones and the values that different communities put on them from their various perspectives. In the late 19th century, Anderson and Pitt Rivers very clearly articulated their different philosophies (see above), and Jones' twenty-first-century community study at Hilton enables 


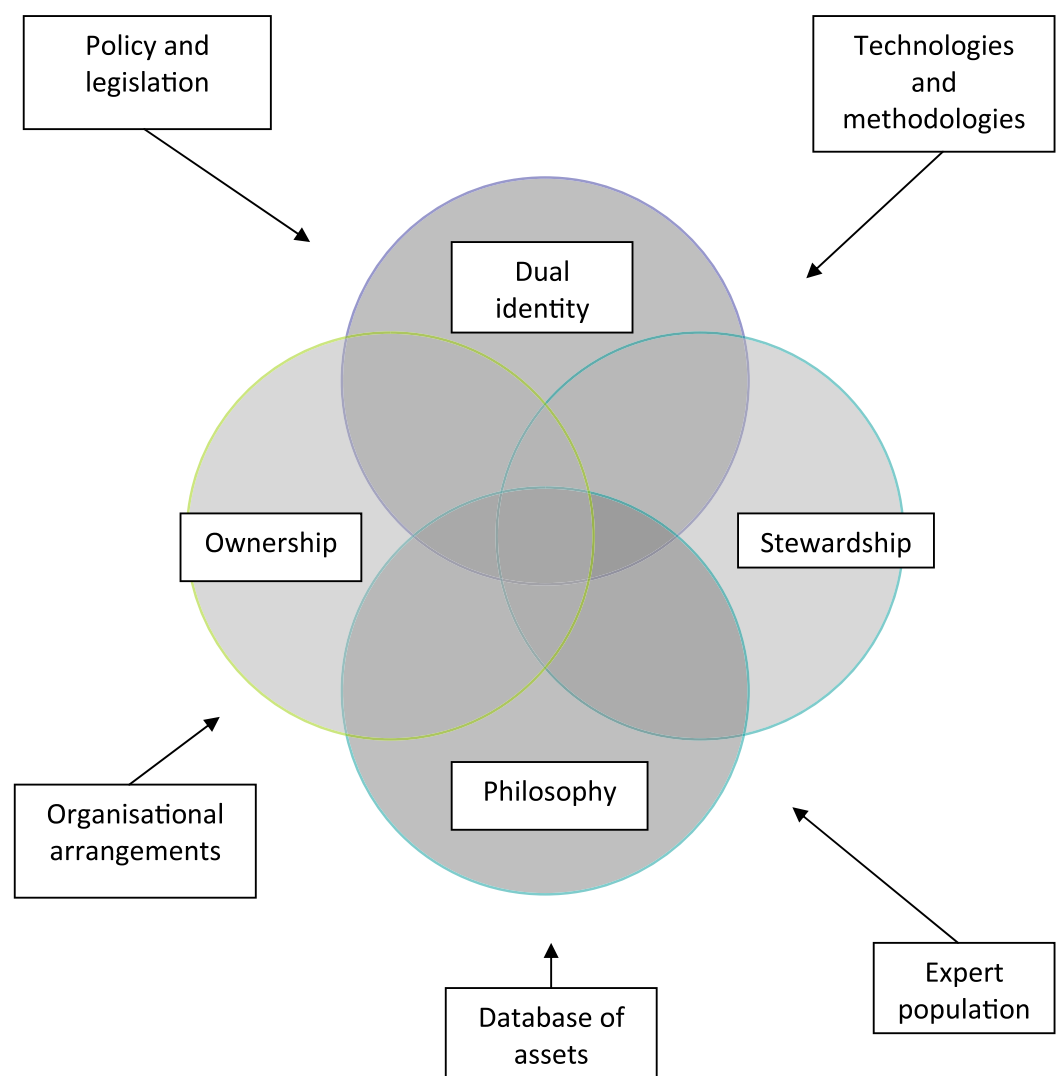

Fig 3 Summary of the relationship between issues relating to carved stones and the character of cultural heritage management

us to draw out and attach meaning to the many different views expressed here too. We can see how attachment to a place is fundamental, but not necessarily conscious until threatened (ibid, 62; 2005a, 37). In the case of carved stones, it is usually the large, highly visible and accessible monuments that enter community consciousness in relation to questions of identity. Historically this has tended to mean early-medieval sculpture because of its modern antiquarian/curatorial history, international significance and vulnerabilities, but also because it is often located in or very close to modern settlement unlike, for example, much prehistoric rock art. How to establish, and how much weight to attach to, such local views relative to other values is a conundrum and very much a live issue for present-day heritage managers.

The character of cultural heritage management, which we can package into five headings, underpins and influences the issues introduced above (Fig 3):

- policy and legislation

- operational arrangements (organisational structures)

- databases of assets 
- techniques and methodologies

- expert population.

\section{Policy and legislation}

Scotland is the only country I am aware of with a government policy for carved stones, but it is still relatively new and known to few, certainly very few outside the profession. Historic Scotland, the government body responsible for safeguarding the historic environment in general, published this in 2005, building on unpublished 1992 policy (subsequently published as an Appendix in Foster 2005). It includes an explicit presumption in favour of the retention, where this is feasible and where permissible under the provision of Treasure Trove, of the physical association of a carved stone with its locality and setting. The emphasis is on actions informed by a full assessment of the cultural significance of a carved stone and its associated site. The location of moved stones is one of the considerations in an assessment of cultural significance, and we now attach a greater weight to the value of secondary locations with our recognition of the importance of carved stone biographies. Pitt Rivers would be content, I feel. In practice, any assessment of the feasibility of moving a carved stone will take into account a whole host of practical considerations, including the conservation needs of a monument and the options to address this, but see Jones $(2006,115)$ for a critique of Historic Scotland's approach, where she argues that this still places an 'overriding emphasis' on demonstrable conservation needs despite recognising, as she welcomes, the need to also factor in social and economic factors. There is also a helpful summary in Gregory 2008 of the evolution of ICOMOS thinking about relocation of monuments, as well as the part that consideration of setting plays in this.

But it is really the legislation and its interpretation that defines artefacts and monuments in terms of curatorial locus. The definition of a portable antiquity is essential for the successful working of the common law Treasure Trove system, while the Ancient Monuments and Archaeological Areas Act 1979 defines what a scheduled monument can be, and for this purpose what a monument is. The listed building legislation, the Planning (Listed Buildings and Conservation Areas) (Scotland) Act 1997, also applies to the protection of carved stones. Historic Scotland 2005, Appendix B seeks to clarify aspects of legal protection of carved stones in general. The 1979 Act's legal definition is about more than the above- or below-ground remains of 'any building, structure or work' or any site comprising such remains, as we shall discover shortly.

Applying the present ancient monuments legislation in relation to carved stones is rarely simple. The wording of the Act is obtuse in respect to our dual identity issue and interpretation of the Act is complex to judge from some of the legal advice that Historic Scotland receives. An observation from a colleague within Historic Scotland sums up the picture nicely:

Trying to follow the argument may lead to temporary mental confusion and should be undertaken only under the supervision of a colleague with at least five years of dealing with the 1979 Act, and even then should only be undertaken when you are feeling particularly clear-headed and well-rested. Do not attempt this on a Friday. 
Suffice to say, the definition of what is a scheduled monument under the terms of the 1979 Act hinges not simply on whether or not something is heritable-fixed to the ground or a structure - or moveable. A moveable structure is schedulable, but only when 'that object or its remains in that particular site [my emphasis] is a matter of public interest' (A.M.A.A.A. 197961 (7) and (8)). The Act does not define 'matter of public interest'. While we cannot schedule a church in use even though it may be a 'building, structure or work', we can schedule a site of a moveable object that is within a heritable church in use, providing that particular site is a matter of public interest. 'Moveable' monument therefore embraces things that in other contexts could also be recognisable as artefacts. Another legal interpretation is that we can also schedule moved objects that are now fixed and therefore heritable within a church in use, providing we exclude the church itself.

\section{Operational arrangements - Our organisations}

The 1882 Ancient Monuments Protection Act not only created a role for the state in the protection of monuments, but it also resulted in the appointment of the first Inspector of Ancient Monuments and the evolution and expansion of central government departments to administer the Act.

Each organisation has its own reason for existing and inevitably develops its own culture, ethos and rhetoric. Different parts of the same organisation may work in silos. Of course, we all know this, and that this can sometimes be a barrier to joined-up thinking and joint working.

Databases of assets: Because different organisations have different roles and responsibilities, we inevitably focus on maintaining databases of assets that focus on our loci and that we may design with different types of internal and external end-users in mind.

Techniques and Methodologies: Because the cultural heritage sector is so diverse, we will bring different sets of eyes and ways of seeing to the same subject matter. We will apply different techniques and methodologies. Think about websites, GIS and databases, for instance. Organisations, departments and individuals are skilled in different ways in their use, and their value for our work and communication with the public may not be universally recognised. We therefore have some way to go before we can make optimum use of the opportunities these tools offer us towards a holistic understanding and communication of the past.

Expert Population: We form an expert population. Tensions may exist between different disciplinary sectors, and we may all be subject to the disdain that the public and politicians alike sometimes apply to those with specialist knowledge and skills. Our specialisms may threaten others or be perceived as intellectual, elitist or partisan; they certainly only represent one series of values.

This brief analysis is admittedly rather introverted and reflects the perspective of someone periodically mired in legal and procedural niceties, and is written by someone who was working in a predominantly monument- rather than artefactorientated organisation. But my message is that these curatorial problems are a 
modern construct and represent the side of looking after our historic environment that is often of little or no interest and relevance to the public, who want to see these carved stones cared for and to be part of that process. Regulation is what the 'official' parties all do, in some capacity or other-and we each use the legislation, our policies, organisational loci and current operational practices to guide us through this. The outcome is that in practice we usually have routes for dealing with carved stone issues through close collaboration tempered by a healthy dose of pragmatism to devise case-specific solutions. While accepting this, there remain some areas where a strategic approach might enable better and more effective protection because it could better anticipate some of the issues identified earlier.

\section{Uniting us and identifying the gaps}

What unites us all is a desire to prevent the loss of the things that we value. When it comes to carved stones, I suggest that there are two generic aspects of harm that we would wish to prevent and in some way unite most people with an interest in carved stones, or an individual carved stone.

- Destruction, loss and decay

- Loss of association (physical or otherwise) with context and setting = place

What underpins these harms and is our ultimate rationale for addressing them, is the loss of our ability to tell the story of Scotland and its communities through its carved stones. Without the story to tell, how can we in Scotland, or our visitors, understand what is so interesting and important about this material in the first place? The latter is critical if we remind ourselves of the cyclical relationship between understanding, valuing, caring and enjoying (Thurley 2005): by understanding the historic environment people value it; by valuing it, they will want to care for it; by caring for it they will help people enjoy it; and from enjoying the historic environment comes a thirst to understand. That critical understanding derives from piecing together all forms of evidence for the past-artefacts and monuments (however they are defined), and landscapes - from all types of sources, and presenting this in a seamless way.

\section{Destruction, loss or decay}

There is a long-running international debate about whether it is acceptable to allow monuments to deteriorate and decay, or indeed to amend their form (see summary in Jones 2006, 112-13, 120-21). Jones characterises this as the distinction between seeing the heritage as a product, i.e. an attempt at physical fossilisation of a particular point in the life of a monument or artefact, or a process, in which the act of ongoing physical change is valued because it is integral to the reproduction of meanings and values by contemporary society.

The answer to this question depends, in part, upon what we want to prioritise through conservation practices; the physical integrity of objects, or their wider cultural significance, which may be linked to intangible and transient values' (ibid, 120); 'each case should be contextualised in terms of the dynamic, culturally specific meanings and values attached to it ... it will be necessary to open up the 
preserves of significance assessment and conservation planning to greater dialogue and negotiation. This may be not be a consensual process: the creation of meaning is often heterogeneous and contested' (ibid, 122).

This is not the place to pursue this particular issue and the question of how we weigh up different values in the conservation planning process. But, regardless, it does highlight the need for us to better understand the nature of what survives, where it is, what condition it is in, and what risks attach to it (such as portability and vulnerability to theft, or vulnerability to physical deterioration, and the pace of that decay). The reason is that any discussions must be evidence-based and informed, not just about the needs of an individual carved stone, but its contribution to our understanding of the resource as a whole. John Higgitt wrote forcefully of the need for a corpus of early-medieval sculpture in Scotland (Higgitt 2005), a need that may apply equally to other categories of carved stones in this country.

We need to continue to research and seek to understand the contemporary meaning of carved stones (what benefits the population in its widest sense can gain for themselves from this material (cf. Jones 2005a, 50)). We also have the option to explore models for supporting local communities to play a greater role in enhanced recording, monitoring and curation of carved stones, to ensure their better preservation.

\section{Loss of association (physical or otherwise) with context and setting}

The need to understand the context of what survives, both individual monuments and their contribution to the understanding of the whole corpus, applies equally. If we take early-medieval carved stones, very few of these survive in what we believe to be their original locations and this special significance needs to be recognised and respected. A subtle but significant shift in the Scottish Government's guidance for carved stones is the emphasis that is also placed on secondary locations that are also significant (Historic Scotland 2005, para 4.3.4). This poses challenges in the sense of our understanding this later history and being able to assess the point after which movement of an individual monument significantly reduces its significance in its own right and to the corpus as a whole, and this is an area where more research could be done.

\section{CONCLUSIONS}

Because of the accidents of history, carved stones (particularly of certain periods) arguably represent the most intellectually and physically fragmented category of monument/artefact in Scotland. To paraphrase Joseph Anderson, and quote him a tiny bit out of context, we must and can avoid 'cultivating our corners' (Anderson 1876, 365) if we are not to exacerbate this fragmentation. Legislation, policy and operational practice will unavoidably influence many aspects of how we approach carved stones, but to bring this material alive and make it relevant to the needs and aspirations of today's public, we need to 'join the fragments' (artefacts/monuments/places), tell the stories and help others to do so. Constructing such (open-ended) biographies will invariably involve today's local communities as active players, and we may need to learn and develop new tools to engage fully 
with each other. This mosaic of local stories is the key to wider understanding, enjoyment, appreciation and care of this enviable Scottish resource, and to building up our bigger picture of what happened in Scotland through time. Several commentators at the RCAHMS Centenary Workshop observed that carved stones could provide us with the most suitable and opportune test bed for the development of collaborative online services that deliver a seamless appreciation of what this national resource can tell us about our past. In this and other ways we can celebrate the way that people and things-monuments and artefacts-enliven one another (cf. James et al 2008, 269).

\section{ACKNOWLEDGEMENTS}

This paper (submitted in February 2009) builds on earlier discussions with the National Committee on the Carved Stones in Scotland and Alan Saville of the Treasure Trove Unit in relation to loose and vulnerable sculpture. I thank Malcolm Cooper for use of his thoughts on the character of heritage management, as presented at the Institute for Archaeologists conference in 2008, and his feedback on an earlier version of this paper, and Mark Hall for his views on the character of the multiple identity of carved stones.

\section{REFERENCES}

Anderson, J. 1876 Notes on the survival of pagan customs in Christian burial ..., Proc. Soc. Antiq. Scot. 11 (1874-6), 363-406.

Anderson, J. 1881 Scotland in Early Christian Times (Second Series). The Rhind Lectures in Archaeology for 1880, Edinburgh: David Douglas.

A.M.A.A.A. 1979 Ancient Monuments and Archaeological Areas Act 1979.

Curtis, N. 2007 'Like stray words or letters'. The development and workings of the Treasure Trove system in B. Ballin Smith, S. Taylor and G. Wells (eds) West over sea. Studies in Scandinavian Sea-Borne Expansion and Settlement Before 1300. A Festschrift in Honour of Dr Barbara E. Crawford, Leiden and Boston: Brill, 341-61.

Foster, S. M. 2001 Place, Space and Odyssey. Exploring the Future of Early Medieval Sculpture, Rosemarkie: Groam House Papers.

Foster, S. M. 2005 Introduction. Able minds and practised hands: historical fact, 21st-century aspiration in S. M. Foster and M. Cross (eds), 1-12.

Foster, S. M. and Cross, M. (eds) 2005 Able Minds and Practised Hands. Scotland's Early Medieval Sculpture in the 21st Century, Leeds: Society for Medieval Archaeology.

Gregory, J. 2008 Reconsidering located buildings: ICOMOS, authenticity and mass relocation, Int. J. Heritage Studies 14:2, 112-30.

Higgitt, J. 2005 Towards a 'new ECMS': the proposal for a new corpus of early medieval sculpture in Scotland in S. M. Foster and M. Cross (eds), 375-9.

Historic Scotland 2005 Carved Stones. Scottish Executive Policy and Guidance, Edinburgh. Available http://www.historic-scotland.gov.uk/carvedstones. Accessed 30 July 2008. 
James, H. F., Henderson, I., Foster, S. M., and Jones, S. 2008 A Fragmented Masterpiece: Recovering the Biography of the Hilton of Cadboll Pictish Cross-slab, Edinburgh: Society of Antiquaries of Scotland.

Jones, S. 2004 Early Medieval Sculpture and the Production of Meaning, Value and Place: The Case of Hilton of Cadboll, Edinburgh: Historic Scotland.

Jones, S. 2005a 'That stone was born here and that's where it belongs': Hilton of Cadboll and the negotiation of identity, ownership and belonging' in S. M. Foster and M. Cross (eds), 37-53.

Jones, S. 2005b Making place, resisting displacement: conflicting national and local identities in Scotland in J. Littler and R. Naidoo (eds) The Politics of Heritage: The Legacies of 'Race', London and New York: Routledge, 94-114.

Jones, S. 2006 'They made it a living thing didn't they': the growth of things and fossilisation of heritage in R. Layton, S. Shennan and P. G. Stone (eds) A Future for Archaeology: The Past in the Present, London: UCL Press, $107-26$.

Scottish Government 2008 Treasure Trove in Scotland: A Code of Practice, Edinburgh.

Thurley, S. 2005 Into the Future. Our Strategy for 2005-2010, Conservation Bulletin 49, 26-7.

\section{Useful websites}

$<$ www.historic-scotland.gov.uk/carvedstones $>$ accessed $10^{\text {th }}$ April 2011

$<$ www.treasuretrovescotland.co.uk $>$ accessed $10^{\text {th }}$ April 2011 